\title{
De invloed van ervaring op de kwaliteit van het accountantsoordeel
}

\section{Niels van Nieuw Amerongen}

SAMENVATTING In de jaren negentig van de vorige eeuw hebben de grootste accountantskantoren hun algemene controlemethodologie herzien naar een op bedrijfsrisico's gebaseerde controlemethodologie. Onderscheidend aan deze controlemethodologie is dat specifieke aandacht wordt besteed aan begrippen als "bedrijfsrisico's van de cliënt" (BR) en "organisatiebrede interne beheersingsmaatregelen" (OIB). Deze begrippen zijn input voor het bepalen van het controlerisico (audit risk). Tot op heden is er nog weinig onderzoek gedaan naar deze nieuwe controlemethodologie. Meer in het bijzonder is van belang onderzoek te doen naar de kwaliteit van het accountantsoordeel bij de toepassing van deze nieuwe methodologie en welke factoren van invloed zijn op de kwaliteit. In dit artikel wordt onderzocht in hoeverre de mate van ervaring van de accountant de kwaliteit van oordeelsvorming beïnvloedt. Drie soorten 'ervaring' worden onderscheiden: algemene- , taakspecifieke- en branchespecifieke ervaring. In dit artikel worden de resultaten beschreven van een experiment waarin de ervaringsinvloed op de kwaliteit van het accountantsoordeel is onderzocht. De resultaten suggereren dat branchespecifieke ervaring bijdraagt aan de kwaliteit van het accountantsoordeel. Dat verband blijkt echter niet-lineair te zijn (een omgekeerde U-vorm curve). Dit zou mogelijk veroorzaakt kunnen worden door het optreden van blinde vlekken.

Dr. C.M. van Nieuw Amerongen RA is partner bij Solutional (dienstverlener op het gebied van Compliance Services en Financial Reporting) en is daarnaast als onderzoeker en docent verbonden aan de Vrije Universiteit Amsterdam. Het artikel is gebaseerd op zijn proefschrift "Auditor's Performance in Risk and Control Judgments" (2007) en een paper, gepresenteerd op het EAA congres te Lissabon. Hij bedankt de congresdeelnemers, Tom Groot en Robert Knechel voor hun feedback. ${ }^{1}$

\section{Introductie}

Ondanks het feit dat er in toenemende mate bij jaarrekeningcontroles gebruik wordt gemaakt van gestandaardiseerde checklists, geldt dat de accountant bij de verschillende onderdelen van het controleproces een complex van factoren in de oordeelsvorming betrekt. De kwaliteit van de oordeelsvorming van de accountant wordt daarom niet alleen bepaald door het in formele zin naleven van voorschriften en procedures, maar ook (en vooral) door de inhoudelijke kwaliteit van afwegingsprocessen. Met dank aan een aantal omvangrijke 'boekhoudschandalen' is er internationaal veel aandacht voor het thema 'kwaliteit van het accountantsoordeel'. In aanvulling hierop is er nog een andere reden waarom onderzoek naar de kwaliteit van het accountantsoordeel belangrijk is, en dat betreft het feit dat de grote accountantskantoren circa tien jaar geleden hun controlemethodologie hebben herzien. Deze nieuwe controlemethodologie wordt aangeduid met "de op bedrijfsrisico's gebaseerde controlemethodologie'. Deze nieuwe controlemethodologie borduurt voort op het traditionele audit risk model en voegt daaraan twee ingrediënten toe:

- Bedrijfsrisico's van de cliënt (BR). Dit betreffen risico's voor de controlecliënt waardoor deze haar strategie en doelstellingen niet kan realiseren.

- Organisatiebrede interne beheersingsmaatregelen (OIB). Dit betreffen maatregelen van interne beheersing die een proces-, of zelfs organisatieomspannend karakter hebben en die erop gericht zijn om materiële fouten in de jaarrekening te ontdekken. Deze maatregelen vormen een aanvulling op de interne beheersingsmaatregelen die op transactieniveau zijn ontworpen en geïmplementeerd .

Een andere ontwikkeling die halverwege de jaren negentig van de vorige eeuw plaatsvond, is dat de grote accountantskantoren branchegroepen hebben opgezet (zie bijvoorbeeld Knechel, 2007; Solomon e.a., 
1999; Hogan en Jeter, 1999). Clustering van kennis en ervaring, alsmede het uitbreiden van het pallet van zogenaamde non-audit services, vormden belangrijke redenen voor deze organisatieaanpassing. Als een gevolg van deze organisatieaanpassing maken individuele accountants onderdeel uit van één bepaalde branche. De kennis van individuele accountants wordt daardoor in belangrijke mate beïnvloed door zowel indirecte branche-ervaring (bijvoorbeeld door het volgen van branchespecifieke trainingen), alsook ook directe branche-ervaring (bijvoorbeeld als gevolg van de jaarrekeningcontrole van branchespecifieke ondernemingen).

In de studie waarover dit artikel rapporteert, wordt de kwaliteit van oordeelsvorming van de accountant onderzocht in twee complexe controletaken, namelijk: het identificeren van bedrijfsrisico's en het identificeren van organisatiebrede interne beheersingsmaatregelen. In voorgaande onderzoeken (zie bijvoorbeeld Bonner, 1990) wordt gesuggereerd dat de kwaliteit van de oordeelsvorming wordt beïnvloed zowel door verschillende eigenschappen van de accountant (zoals bijvoorbeeld het ervaringsniveau van de accountant) maar ook door de controletaak, waarbij vooral de mate van complexiteit van de taak van belang is. Tot op heden is er nog relatief weinig onderzoek gepubliceerd naar de kwaliteit van oordeelsvorming van de accountant bij het uitvoeren van taken die behoren tot de op bedrijfsrisico's gebaseerde controleaanpak. Omdat deze controlemethodologie relatief nieuw is, zou verwacht kunnen worden dat de kwaliteit van oordeelsvorming momenteel nog niet optimaal is. Accountants moeten nu eenmaal wennen aan een nieuw gedachtegoed en het vergt tijd voordat deze aanpak is ingebed in de controlepraktijk. In het bijzonder worden in deze studie drie soorten van ervaring van de accountant betrokken, waarvan de invloed op de kwaliteit van oordeelsvorming wordt onderzocht, te weten: (1) algemene ervaring van de accountant, (2) taakspecifieke ervaring, en (3) branchespecifieke ervaring. Deze drie soorten ervaring zijn nog niet eerder gezamenlijk onderzocht. De uitkomsten van dit onderzoek dragen om die reden bij aan gedragswetenschappelijk onderzoek naar ervaringseffecten, maar in het bijzonder ook aan studies naar de kwaliteit van de op bedrijfsrisico's gebaseerde controleaanpak.

In paragraaf 2 wordt de voor de onderzoeksvraag relevante theorie besproken, waarin de onderzoekshypothesen zijn ingebed. In paragraaf 3 komen de onderzoeksopzet en de onderzoeksresultaten aan bod. Dit artikel sluit af met een conclusie over de relevantie van de onderzoeksresultaten en de beperkingen van deze studie.

\section{Theorie en onderzoekshypothesen}

Het gedragswetenschappelijke onderzoek in de accountancy vindt haar oorsprong in de discipline van de cognitieve psychologie. Veel onderzoeken op dit terrein richten zich op het opsporen van eigenschappen van de accountant die van invloed zijn op de kwaliteit van oordeelsvorming. Vanaf de jaren tachtig zijn onderzoeksstromingen opgestart die zich met name richten op de eigenschap 'algemene ervaring van de accountant. Het beeld dat uit deze onderzoeken naar voren komt is gemengd: zowel een positieve als een negatieve invloed van algemene ervaring op de kwaliteit van oordeelsvorming (zie voor een overzicht bijvoorbeeld Trotman, 1998). Als verklaring voor deze gemengde onderzoeksresultaten wordt gesteld dat de mate van taakcomplexiteit daarvoor verantwoordelijk is (zie bijvoorbeeld Early, 2002; Wright, 1988; Abdolmohammadi en Wright, 1987). Abdolmohammadi en Wright (1987) rapporteren bijvoorbeeld dat ervaren accountants in het algemeen beter presteren dan relatief onervaren accountants als het gaat om de meer complexe controletaken. Gebaseerd op de hiervoor aangehaalde studies kan geconcludeerd worden dat de eigenschap 'algemene ervaring' onvoldoende onderscheidend is om prestatieverschillen tussen accountants te kunnen verklaren.

De gerapporteerde prestatieverschillen tussen accountants hebben onderzoekers ertoe gebracht om de eigenschap 'algemene ervaring' nader te specificeren in termen van taakcomplexiteit, in deze studie aangeduid met 'taakspecifieke ervaring'. Bijvoorbeeld Bonner (1990) voert een experiment uit met betrekking tot een tweetal controletaken die variëren in de mate van taakcomplexiteit: een controletaak waarbij de accountant het intern beheersingsrisico inschat (een relatief eenvoudige taak) en een controletaak waarbij de accountant een cijferbeoordelingsrisico (onderdeel van 'ontdekkingsrisico', een complexere taak) inschat. Haar onderzoeksresultaten suggereren dat taakspecifieke kennis (ervaring) alleen de prestaties verbeteren voor de complexere taak. Soortgelijke resultaten, bijvoorbeeld ten aanzien van het herkennen van bepaalde patronen in financiële cijfers, worden gerapporteerd door Bedard en Biggs (1991a; 1991b) en Davis en Solomon (1989).

Het preciseren van ervaringseigenschappen heeft zich in de jaren negentig verder doorgezet toen de grote accountantskantoren zich gingen organiseren rond branches. In de praktijk betekende dit dat vooral voor wat betreft de in hoge mate gereguleerde branches (financiële sector, overheid, en gezondheidszorg) 
accountants een branchespecifieke cliëntenportefeuille kregen toegewezen binnen het accountantskantoor. Voor de minder gereguleerde branches is de mate van branchespecialisatie van een lagere orde. De accountantskantoren hadden verschillende redenen voor de structurering rond branches, zoals bijvoorbeeld:

- het leveren van meer toegevoegde waarde aan controlecliënten door het opzetten van branchespecifieke kennisdatabases;

- het verhogen van de kwaliteit van de accountantscontrole. Door een clustering van branchekennis is de accountant, zo werd betoogd, beter in staat om branchespecifieke risico's goed in te schatten, de organisatie en omgeving van de cliënt beter te begrijpen en daardoor met een gerichte controleaanpak voor de dag te komen (een verbetering van zowel de efficiency als de effectiviteit van de controle).

In deze studie wordt onderzocht in welke mate branchespecifieke ervaring bijdraagt aan de kwaliteit van oordeelsvorming. Eerdere onderzoeken, zoals bijvoorbeeld van Solomon e.a. (1999), suggereren dat branchespecifieke ervaring helpt om de cliëntorganisatie en -omgeving beter te begrijpen, maar dat dit niet noodzakelijkerwijs leidt tot het vinden van meer materiële fouten in de jaarrekening. In een ander onderzoek rapporteert Taylor (2000) dat nietgespecialiseerde accountants (in dat onderzoek: accountants die niet gespecialiseerd zijn in de bancaire sector) conservatiever waren in risico-inschattingen en minder zelfvertrouwen hadden in de uitgevoerde inschattingen vergeleken met gespecialiseerde accountants. Daarnaast rapporteert Taylor dat gespecialiseerde accountants een betere prestatie leveren bij het inschatten van het inherent risico van een branchespecifieke jaarrekeningpost vergeleken met accountants die niet gespecialiseerd zijn. Wright en Wright (1997) betrokken de mate van branchespecialisatie in de retailbranche (een minder gereguleerde branche) in hun onderzoek. In een casusbeschrijving verpakten zij vier materiële fouten, waarvan er drie gerelateerd waren aan de retailbranche. De resultaten van hun experiment suggereren dat branchespecifieke ervaring bijdraagt aan het genereren van hypothesen bij het identificeren van jaarrekeningfouten, maar dat dit niet leidt tot de verwachte risico-inschattingen. Wanneer wij deze resultaten vergelijken met die van Taylor, dan zou een van de verklaringen voor de verschillende resultaten gelegen kunnen zijn in het verschil van branche (bancaire sector versus retailbranche).
In deze studie onderzoek ik de prestaties van accountants bij het uitvoeren van twee controletaken, die beide gekwalificeerd kunnen worden als in hoge mate ongestructureerd, te weten: de identificatie van bedrijfsrisico's en de identificatie van organisatiebrede interne beheersingsmaatregelen. De gegeven kwalificatie is 'ongestructureerd', vanwege het onbekende aantal (juiste) factoren dat dient te worden geïdentificeerd. Ook vraagt de taak veel (professionele) oordeelsvorming (bijvoorbeeld het inschatten van de mate van relevantie voor elk van de geïdentificeerde factoren) en daarnaast impliceert de aard van de taak dat een speurtocht in een aantal uiteenlopende bronnen dient plaats te vinden (bijvoorbeeld kennisname van de kennisdatabases van het accountantskantoor, internet, strategiebeschrijvende documenten van de gecontroleerde onderneming, interviews met kernfunctionarissen van de gecontroleerde onderneming). Vanwege de hoge mate van taakcomplexiteit zouden wij verwachten dat ervaring - of deze nu van algemene aard, van taak- dan wel van branchespecifieke aard is - positief bijdraagt aan de kwaliteit van oordeelsvorming. Resumerend leidt de bovenstaande analyse tot de volgende hypothesen:

H1: De kwaliteit van het accountantsoordeel correleert positief met de mate van algemene ervaring in de accountancy.

$\mathrm{H} 2$ : De kwaliteit van het accountantsoordeel correleert positief met de mate van taakspecifieke ervaring.

H3: De kwaliteit van het accountantsoordeel correleert positief met de mate van branchespecifieke ervaring.

\section{Opzet van het onderzoek}

\section{a. Onderzoeksdeelnemers}

De onderzoeksdeelnemers kregen een beschrijving van een casusbedrijf, actief in de bouwbranche, voorgelegd op basis waarvan zij gevraagd werden de vijf meest relevante bedrijfsrisico's en de vijf belangrijkste organisatiebrede interne beheersingsmaatregelen te identificeren. Aan het onderzoek namen 85 accountants van het niveau 'manager' - werkzaam bij de Big Four - deel. Het niveau 'manager' was geselecteerd omdat dit functieniveau impliceert dat alle deelnemende accountants voldoende ervaring hebben met identificatietaken. Binnen de groep van deelnemers kon nader onderscheid gemaakt worden tussen accountants mét en accountants zonder ervaring in de bouwbranche. Gemiddeld genomen hadden de accountants 13 jaar ervaring in de accountancy, besteedden zij in de achter- 
liggende drie jaar gemiddeld 688 uur aan de controle van bouwbedrijven en hadden zij beide identificatietaken gemiddeld zeven keer per jaar uitgevoerd. Gemiddeld genomen besteedden zij an het identificeren van bedrijfsrisico's ongeveer 35 uur op jaarbasis en het identificeren van organisatiebrede interne beheersingsmaatregelen 70 uur op jaarbasis.

\section{b. Maatstaven voor prestatiemeting (afhankelijke variabelen)}

In deze studie wordt de kwaliteit van oordeelsvorming (prestatiemeting) gemeten door een nauwkeurigheidsmaatstaf ("accuracy"). Doorgaans bestaat bij het uitvoeren van een experiment de moeilijkheid om een extern valide criterium te vinden waarmee de oordelen van accountants vergeleken en dus gemeten kunnen worden. De nauwkeurigheidsscores van de deelnemende accountants werden bij deze studie gemeten met gebruikmaking van de oordeelsvorming van een apart expert panel. Doorgaans wordt in de psychologische literatuur onderscheid gemaakt tussen novieten (bijvoorbeeld beginnende assistent accountants), ervarenen (bijvoorbeeld accountants van het niveau 'manager') en experts. Hierbij wordt direct aangetekend dat in het algemeen ook experts bloot staan aan het maken van inschattingsfouten (zie bijvoorbeeld Conlisk, 1996). Niets menselijks is hen vreemd. Om die reden is een panel van experts samengesteld om de benchmark nog sterker te maken. Het panel was zorgvuldig samengesteld en bestond uit de vier "industry leaders" van de bouwbranche binnen het accountantskantoor; ieder panellid was partner bij één van de Big Four-kantoren en medeverantwoordelijk voor het branchebeleid binnen het accountantskantoor waarin zij werkzaam waren. Van deze partners kon daarom worden verondersteld dat zij een overview hadden over de ontwikkelingen die gaande waren binnen de bouwbranche. Verder geldt van deze partners ook dat zij veelvuldig contact hadden met hun belangrijkste cliënten in de bouwbranche en dat zij mede verantwoordelijk waren voor het interne branchespecifieke opleidingsbeleid en het up-to-date houden van interne branchespecifieke databases. Het niveau van 'partner' impliceert veelal ook dat zij een bredere cliëntenportefeuille hebben vergeleken met managers, waardoor zij in potentie minder last hebben van bovenmatige invloeden van cliëntspecifieke situaties.

Voordat het experiment plaatsvond, werd een bijeenkomst van het expertpanel georganiseerd. Aan de experts werd eenzelfde casusbeschrijving voorgelegd als aan de deelnemers aan het experiment dat op een latere datum plaatsvond. De bijeenkomst van het expertpanel was als volgt van opzet:

- De experts werd gevraagd om de vijf belangrijkste bedrijfsrisico's (vanuit cliëntperspectief) te identificeren. Aan de hieruit voortvloeiende lijst van bedrijfsrisico's wordt gerefereerd bij het berekenen van de eerste nauwkeurigheidsscore van deelnemers aan het experiment.

- Aansluitend compileerde de onderzoeker de antwoorden tot een totaallijst van belangrijkste bedrijfsrisico's, resulterend in een lijst van 15 bedrijfsrisico's (van de 20 denkbare bedrijfsrisico's waren er vijf een doublure).

- Daarna werden de experts verzocht de vijf belangrijkste (in termen van mitigeren van bedrijfsrisico's) organisatiebrede interne beheersingsmaatregelen te identificeren. Aan de hieruit voortvloeiende lijst van organisatiebrede interne beheersingsmaatregelen wordt gerefereerd bij het berekenen van de tweede nauwkeurigheidsscore.

- De onderzoeker vatte deze lijst samen, resulterend in een lijst van 21 organisatiebrede interne beheersingsmaatregelen.

Een overzicht van gehanteerde onderzoeksvariabelen is opgenomen in Tabel 1. De berekeningswijze van de nauwkeurigheidsscores wordt in Tabel 2 gepresenteerd (zie pagina 382).

\section{c. Onafhankelijke variabelen}

Onderstaand worden de volgende onafhankelijke variabelen die in de onderzoeksopzet zijn betrokken, meer in detail besproken: (1) algemene ervaring in de accountancy, (2) taakspecifieke ervaring, en (3) branchespecifieke ervaring.

\section{Algemene ervaring in de accountancy}

Op basis van reeds gepubliceerde studies (zie voor een overzicht: Wright, 1988; Trotman, 1998), is algemene ervaring in de accountancy vaak gebruikt als maatstaf voor de expertise van de accountant. Enkele studies gebruikten functieniveau als 'proxy' voor algemene ervaring. In deze studie wordt algemene ervaring gemeten in termen van het aantal jaren dat de accountant werkzaam is in de accountancy. Een belangrijk voordeel van een dergelijke continue variabele - vergeleken met een niet-continue variabele is dat het in vergelijking met andere onafhankelijke variabelen, die ook op een continue schaal gemeten worden, methodologisch eenvoudiger maakt.

\section{Taakspecifieke ervaring}

Met betrekking tot het meten van taakspecifieke ervaring worden in eerdere onderzoeken verschillende 


Tabel 1 Beschrijving onderzoeksvariabelen
\begin{tabular}{|l|l|}
\hline Naam variabele & Beschrijving \\
\hline ACC1 & Kwaliteit van oordeelsvorming bij de taak 'identificatie van bedrijfsrisico's'. \\
\hline ACC2 & Kwaliteit van oordeelsvorming bij de taak 'identificatie van organisatiebrede interne beheersingsmaatregelen. \\
\hline GENEXP & Algemene ervaring, gemeten in aantallen jaren werkervaring in de accountancy. \\
\hline ISEXP & $\begin{array}{l}\text { Branchespecifieke ervaring, gemeten als het geschatte aantal uren dat accountants in de afgelopen } 3 \text { jaar hebben besteed } \\
\text { aan de jaarrekeningcontrole van bouwbedrijven. }\end{array}$ \\
\hline TSEXPCBR & $\begin{array}{l}\text { Taakspecifieke ervaring behorend bij de taak 'identificatie van bedrijfsrisico's', gemeten als het aantal keren dat de taak in het } \\
\text { achterliggende jaar werd uitgevoerd. }\end{array}$ \\
\hline TSEXPELC & $\begin{array}{l}\text { Taakspecifieke ervaring behorend bij de taak 'identificatie van organisatiebrede interne beheersingsmaatregelen', gemeten als het } \\
\text { aantal uren dat het afgelopen jaar aan deze taak werd besteed. }\end{array}$ \\
\hline
\end{tabular}

Tabel 2 Berekeningswijze individuele nauwkeurigheidsscores deelnemers experiment

\begin{tabular}{|l|l|l|l|}
\hline Afk. & Taak & Aard & Berekeningswijze \\
\hline ACC1 & Identificatie van bedrijfsrisico's & Factor nauwkeurigheid & $\begin{array}{l}\text { Aantal door de accountant geïdentificeerde bedrijfsrisico's dat overeenstemt } \\
\text { met de lijst van het expert panel (maximum = 5). }\end{array}$ \\
\hline ACC2 & $\begin{array}{l}\text { Identificatie van organisatiebrede } \\
\text { interne beheersingsmaatregelen }\end{array}$ & Factor nauwkeurigheid & $\begin{array}{l}\text { Aantal door de accountant geïdentificeerde organisatiebrede interne } \\
\text { beheersingsmaatregelen dat overeenstemt met de lijst van het expert panel } \\
\text { (maximum =5). }\end{array}$ \\
\hline
\end{tabular}

maatstaven gebruikt. In sommige studies (bijvoorbeeld in Bonner, 1990) wordt de deelnemersgroep opgesplitst in een relatief ervaren en een relatief onervaren groep, gebruikmakend van een afkapgrens voor taakspecifieke ervaring. Het onderzoek van Bonner betrof een tweetal controletaken die al sedert jaren onderdeel uitmaken van de reguliere controleaanpak. Bij de voorliggende studie is dat niet het geval. Om die reden is ervoor gekozen om taakspecifieke ervaring zo zuiver mogelijk te meten door de accountants te vragen een expliciete inschatting van het aantal keren en de daarmee gemoeide ervaringstijd te maken. Deze inschattingen zijn direct gekoppeld aan de twee controletaken die in het onderzoek zijn betrokken.

\section{Branchespecifieke ervaring}

Op dit moment bestaat er nog geen algemeen geaccepteerde of gangbare maatstaf om branchespecifieke ervaring te meten (zie ook Wright en Wright, 1997). In voorgaande onderzoeken worden variabelen gebruikt als 'door het accountantskantoor al dan niet aangewezen als specialist' (bijvoorbeeld in Wright en Wright, 1997; Solomon e.a., 1999), 'het aantal keren dat een jaarrekeningcontrole van een branchespecifieke cliënt is uitgevoerd' (bijvoorbeeld in: Taylor, 2000; Wright en Wright 1997), 'aantal trainingsuren in een specifieke branche', en 'aantal jaren ervaring (niet als openbare accountant) in een specifieke branche'
(Wright and Wright, 1997). Geen van deze maatstaven wordt tot op heden als algemeen geaccepteerde variabele beschouwd. In het uitgevoerde experiment is als maatstaf genomen: het aantal uren dat in de afgelopen drie jaar werd besteed aan de jaarrekeningcontrole van bouwbedrijven. Over een langere periode (drie jaar) bezien, is het meer aannemelijk dat ervaring in de bouwbranche zuiver wordt gemeten vergeleken met een maatstaf gebaseerd op één enkel jaar.

\section{c. Onderzoeksmateriaal}

Op het casusmateriaal en de vragenlijst (inclusief de "debriefing"-questionnaire) werden pilot testen gedaan voordat het expert panel bijeenkwam en het experiment plaatsvond. Zowel in de praktijk werkzame accountants als onderzoekers namen aan de pilottesten deel. Het bleek op basis van die pilottesten niet nodig om wijzigingen aan te brengen in het ontwikkelde materiaal.

Voordat het experiment plaatsvond, werd contact opgenomen met de vaktechnische bureaus van het deelnemende accountantskantoor om de deelname van de accountantskantoren aan het onderzoek te bespreken. Voor elk accountantskantoor werd een vertegenwoordiger aangewezen die als centraal coördinatiepunt fungeerde met het oog op het selecteren van geschikte deelnemers aan het experiment (managers met en managers zonder branchespecifieke ervaring) 
en het distribueren van in te vullen vragenlijsten en aansluitend verzamelen van ingevulde vragenlijsten.

Het onderzoeksmateriaal bevatte een introductiebrief voor deelnemende accountants die relevant was voor het invullen van de vragenlijst. Deze introductiebrief bevatte definities van relevante begrippen (bijvoorbeeld 'bedrijfsrisico's' en 'organisatiebrede interne beheersingsmaatregelen') en instrueerde de accountants om geen gebruik te maken van de kennis en ervaring van collega's of andere hulpmiddelen. Hoewel deze specifieke procedure enigszins afwijkt van hoe de betreffende controletaak in de praktijk wordt uitgevoerd, was deze instructie nodig om zo zuiver individuele ervaringseffecten te onderzoeken.

\section{Onderzoeksresultaten}

\section{a. Beschrijvende statistieken}

Tabel 3 bevat beschrijvende statistieken met betrekking tot de gemiddelde kwaliteit van oordeelsvorming van accountants.

Gemiddeld genomen scoorden accountants 2.46 op de eerste nauwkeurigheidsmaatstaf (ACC1) met een maximum van 5.00 voor de identificatie van bedrijfsrisico's. Met betrekking tot de taak 'identificatie van organisatiebrede interne beheersingsmaatregelen' scoorden accountants gemiddeld 3.68 (ACC2) met een maximum van 5.00. Deze gemiddelde scores suggereren dat gemiddeld genomen de kwaliteit van oordeelsvorming ruimte voor verbetering bevat.

\section{b. Toetsen van hypothesen}

Onderstaand wordt eerst beschreven of en in welke mate de onafhankelijke variabelen gezamenlijk invloed hebben op de kwaliteit van oordeelsvorming. Daartoe is een regressiemodel opgesteld. Aansluitend zal de invloed van individuele onafhankelijke variabelen verder worden beschreven, gebruik makend van correlaties.

\section{Regressiemodel kwaliteit van oordeelsvorming en ervaringsvariabelen}

Tabel 4 rapporteert de resultaten van het regressiemodel voor de eerste nauwkeurigheidsscore betreffende de identificatie van bedrijfsrisico's.

Het regressiemodel zelf is marginaal significant $(\mathrm{p}=$ .077). Daarnaast zijn de variabelen 'branchespecifieke ervaring' en 'taakspecifieke ervaring met betrekking tot het identificeren van organisatiebrede interne beheersingsmaatregelen' marginaal significant. Merk op dat de bèta van laatste genoemde variabele negatief is.

Tabel 5 toont de resultaten van het regressiemodel voor de tweede nauwkeurigheidsscore betreffende de taak identificatie van organisatiebrede interne beheersingsmaatregelen'. Het regressiemodel is significant $(\mathrm{p}=.017)$.

\section{i. Algemene ervaring in de accountancy}

Tabel 6 toont de eenzijdige Pearson correlaties tussen de kwaliteit van oordeelsvorming, gemeten door ACC1 en ACC2, en de onderscheiden categorieën ervaring.

Tabel 3 Beschrijvende statistieken nauwkeurigheidsscores

\begin{tabular}{|l|l|l|l|l|l|l|l|}
\hline Variabele & $\mathbf{n}$ & $\begin{array}{l}\text { Werkelijk } \\
\text { minimum }\end{array}$ & $\begin{array}{l}\text { Theoretisch } \\
\text { minimum }\end{array}$ & $\begin{array}{l}\text { Werkelijk } \\
\text { maximum }\end{array}$ & $\begin{array}{l}\text { Theoretisch } \\
\text { maximum }\end{array}$ & Ge-middelde & $\begin{array}{l}\text { Standaard } \\
\text { deviatie }\end{array}$ \\
\hline ACC1 & 85 & 1.00 & .00 & 5.00 & 5.00 & 2.46 & 1.03 \\
\hline ACC2 & 85 & 1.00 & .00 & 5.00 & 5.00 & 3.68 & 1.84 \\
\hline
\end{tabular}

Tabel 4 Regressiemodel kwaliteit van oordeelsvorming (ACC1) en algemene ervaring (GENEXP), branchespecifieke ervaring (ISEXP), en taakspecifieke ervaring (TSEXP)

\begin{tabular}{|l|l|l|l|}
\hline Variabele & Beta & T-Statistiek & Significantie \\
\hline GENEXP & -.107 & -.941 & .175 \\
\hline ISEXP & .142 & 1.314 & .097 \\
\hline TSEXPCBR & .010 & .051 & .480 \\
\hline TSEXPELC & -.271 & -1.401 & .083 \\
\hline CONSTANT & n.v.t. & 10.686 & .000 \\
\hline
\end{tabular}

Adjusted $R^{2}=.055 ;$ Significantie $=.077^{*}$

Voor de namen van de variabelen wordt verwezen naar Tabel 1 
Uit Hypothese 1 volgt een verwachte positieve invloed van algemene ervaring op de kwaliteit van oordeelsvorming. In Tabel 6 wordt een negatieve, niet-significante correlatie gerapporteerd voor de taak identificatie van bedrijfsr isico's' (-.028) en een marginaal significante positieve correlatie voor de taak 'identificatie van organisatiebrede interne beheersingsmaatregelen' (.164). Daarom kan hypothese 1 verworpen worden voor wat betreft de taak 'identificatie van bedrijfsrisico's'.

\section{ii. Taakspecifieke ervaring}

Uit Hypothese 2 volgt een verwachte positieve relatie tussen taakspecifieke ervaring en de kwaliteit van oordeelsvorming. Tabel 6 rapporteert echter significante negatieve correlaties voor wat betreft ACC1. Voor wat betreft ACC2 (identificatie van organisatiebrede interne beheersingsmaatregelen) worden geen significante correlaties gerapporteerd. Deze onderzoeksresultaten zijn in tegenspraak met onze eigen verwachtingen en eerder gerapporteerde onderzoeken (zie bijvoorbeeld Bonner, 1990; Bonner en Lewis, 1990). Een potentiële verklaring zou kunnen zijn dat accountants worden gehinderd door een 'teveel' aan cliëntspecifieke kennis. In een identificatietaak gaat de accountant op zoek naar relevante informatie in een variëteit van kennisdatabases en overweegt de accountant hoe de te onderzoeken cliëntsituatie zich verhoudt tot eerdere ervaringen bij soortgelijke cliënten. Voor wat betreft het identificeren van bedrijfsrisico's is echter veelal sprake van unieke situaties, waarvan de kennis opgedaan bij andere cliënten maar ten dele overdraagbaar is of toepasbaar is op nieuwe situaties. Het is overigens ook denkbaar dat de deelnemende accountants bij het uitvoeren van de controletaken in dit onderzoek gehinderd waren door het niet mogen gebruiken van hulpmiddelen. Het is aan te bevelen de onderzoeksresultaten van deze studie in de toekomst nader te bestuderen om zodoende meer licht te werpen op de vraag wat taakspecifieke ervaring doet met mensen. Een verbaal-protocol type onderzoek zou in dat kader geschikt kunnen zijn.

\section{iii. Branchespecifieke ervaring}

Uit Hypothese 3 volgt een verwachte positieve relatie tussen branchespecifieke ervaring en de kwaliteit van oordeelsvorming. In Tabel 6 worden voor beide controletaken significante positieve eenzijdige Pearson correlaties gerapporteerd (correlaties van $.158(\mathrm{p}=.075)$ en $.195 \quad(\mathrm{p}=.038)$ respectievelijk). Daarom kan hypothese 3 niet verworpen worden. Echter, bij verder exploratief onderzoek naar de gevonden correlaties werd bij de taak 'identificatie van bedrijfsrisico's' (ACC1) geconstateerd dat wanneer de totale groep van accountants werd onderverdeeld naar subgroepen - de positieve correlatie hoofdzakelijk wordt veroorzaakt door de relatief

Tabel 5 Regressiemodel kwaliteit van oordeelsvorming (ACC2) en algemene ervaring (GENEXP), branchespecifieke ervaring (ISEXP), en taakspecifieke ervaring (TSEXP)

\begin{tabular}{|l|l|l|l|}
\hline Variabele & Beta & T-Statistiek & Significantie \\
\hline GENEXP & .141 & 1.258 & .106 \\
\hline TSEXPCBR & .188 & 1.233 & .111 \\
\hline TSEXPELC & -.185 & -1.210 & .115 \\
\hline ISEXP & .261 & 2.347 & $.011^{*}$ \\
\hline CONSTANT & n.v.t. & 8.190 & $.000^{*}$ \\
\hline
\end{tabular}

Adjusted $R^{2}=.078 ;$ Significantie $=.017^{*}$

Voor de namen van de variabelen wordt verwezen naar Tabel 1

Tabel 6 Correlatiematrix van afhankelijke en onafhankelijke variabelen

\begin{tabular}{|l|l|l|l|l|l|l|}
\hline & ACC1 & ACC2 & GENEXP & ISEXP & TSEXPCBR \\
\hline ACC1 & 1.000 & $.230^{*}(.034)$ & $-.028(.401)$ & $.158^{*}(.075)$ & $-.178^{*}(.055)$ \\
\hline ACC2 & & 1.000 & $.164^{*}(.070)$ & $.195^{*}(.038)$ & $.071(.262)$ \\
\hline GENEXP & & & 1.000 & $.008(.947)$ & $.018(.870)$ & $-.052(.321)$ \\
\hline ISEXP & & & & 1.000 & $-.164(.141)$ \\
\hline TSEXPCBR & & & & & & \\
\hline TSEXPELC & & & & & & \\
\hline
\end{tabular}

Significant: $=p<.1$ 
onervarenen (in termen van branchespecifieke ervaring). De subgroep van meest ervarenen toonde juist een negatieve correlatie. Dit suggereert dat er sprake is van een niet-lineair verband tussen de mate van branchespecifieke ervaring en de kwaliteit van oordeelsvorming. Daarom is aanvullend nog een regressiemodel met een niet-lineaire vorm opgesteld. De resultaten van dit regressiemodel worden gerapporteerd in Tabel 7.

Het regressiemodel is marginaal significant ( $\mathrm{p}=.097)$. Daarnaast zijn alle modelcomponenten significant en verklaren 3,2 procent van de totale variantie in de kwaliteit van oordeelsvorming. Deze resultaten vormen een indicatie dat tot op zekere hoogte dit niet-lineaire verband inderdaad aanwezig is. Figuur 1 toont de verwachte waarden van de kwaliteit van oordeelsvorming versus de mate van branchespecifieke ervaring.

Figuur 1 suggereert dat de kwaliteit van oordeelsvorming toeneemt bij een toename van branchespecifieke ervaring tot een niveau van ongeveer 1.200 uren branchespecifieke ervaring. Vanaf dit niveau van branchespecifieke ervaring en hoger ontstaat een tendentie tot afname van de kwaliteit van oordeels-

Figuur 1 Verwachte kwaliteit van oordeelsvorming (ACC1) versus branchespecifieke ervaring

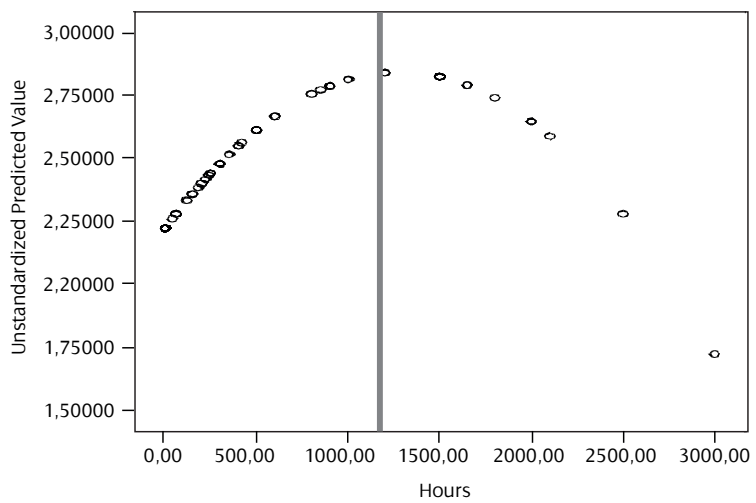

vorming. Eerdere onderzoeken hebben dergelijke 'omgekeerde leercurves' niet gerapporteerd. Wel wordt bijvoorbeeld door Bedard en Graham (2002) gewezen op het risico van 'blinde vlekken. Blinde vlekken kunnen bijvoorbeeld optreden wanneer een accountant een bepaalde eenzijdigheid heeft in de cliëntenportefeuille (teveel focus op een bepaalde branche of teveel uren besteed aan een relatief klein aantal grote cliënten). Aanvullend toekomstig onderzoek is nodig om deze onderzoeksresultaten verder te brengen tot een nieuwe theorie. Daarnaast verdient het aanbeveling om in toekomstig onderzoek ook andere branches te betrekken om te bezien of de in dit artikel gepresenteerde onderzoeksresultaten ook in andere branches van toepassing zijn.

\section{Discussie en beperkingen}

De resultaten van deze studie suggereren dat algemene ervaring bijdraagt aan de kwaliteit van oordeelsvorming bij het identificeren van organisatiebrede interne beheersingsmaatregelen. Eerdere onderzoeken hebben gemengde resultaten gerapporteerd. In dat licht bezien, sluiten de in dit artikel gerapporteerde onderzoeksresultaten aan op eerdere onderzoeken, aangezien voor de taak identificatie van bedrijfsrisico's' geen bevestiging werd gevonden voor de gestelde hypothese. De gevonden onderzoeksresultaten kunnen mogelijk verklaard worden doordat de accountant traditioneel meer bekend is met beheersingssystemen dan met bedrijfsrisico's en de kennis betreffende interne beheersingssystemen ook toepasbaar is in andere cliëntsituaties.

In de tweede plaats en tegengesteld aan onze verwachtingen wordt een significant negatieve invloed van taakspecifieke ervaring op de kwaliteit van oordeelsvorming gerapporteerd bij de identificatie van bedrijfsrisico's. De setting in het experiment sluit niet geheel aan op de praktijk, aangezien accountants in het experiment gevraagd werd geen gebruik te mogen maken van hulpmiddelen. Indien dat wel het geval was geweest, waren de uitkomsten van dit onderzoek mogelijk ook anders geweest.

Tabel 7 Niet-lineair regressiemodel (kwaliteit van oordeelsvorming (ACC1) en branchespecifieke ervaring)

\begin{tabular}{|l|l|l|l|}
\hline Variabele & Beta & T-Statistiek & Significantie \\
\hline ISEXP & .647 & 2.146 & $.035^{*}$ \\
\hline ISEXP*ISEXP & -.557 & -1.849 & $.068^{*}$ \\
\hline CONSTANT & n.v.t. & 14.155 & $.000^{*}$ \\
\hline
\end{tabular}

Adjusted $R^{2}=.032 ;$ Significantie $=.097^{*}$ 
Ten slotte werd voor de derde hypothese, die een positief verband verwacht tussen branchespecifieke ervaring en de kwaliteit van oordeelsvorming, support verkregen. Echter, op basis van nader exploratief onderzoek wordt gesuggereerd dat een omgekeerde U-leercurve optreedt bij het identificeren van bedrijfsrisico's. Blinde vlekken en de veronderstelling dat elke cliëntsituatie relatief uniek is, kunnen hiervoor verklarende factoren zijn.

De onderzoeksresultaten zijn van groot belang voor de leiding van accountantskantoren die zich hebben gespecialiseerd in een bepaalde branche. Een belangrijk element van het systeem van kwaliteitsbeheersing van accountantskantoren is het beleid ten aanzien van de teamsamenstelling op controleopdrachten. De teamsamenstelling heeft een belangrijke invloed op de kwaliteit van de uitgevoerde controleopdrachten. Met de uitkomsten van het in dit artikel gerapporteerde onderzoek bestaat er meer inzicht in een aantal determinanten (namelijk algemene-, taakspecifieke-, en branchespecifieke ervaring) van de kwaliteit van het accountantsoordeel. Expliciete overweging van de teamsamenstelling kan de kwaliteit van de accountantscontrole positief dan wel negatief beïnvloeden. De uitkomsten van dit onderzoek onderstrepen daarom het feit dat elke accountant unieke ervaringseigenschappen bezit, en dat deze ervaringseigenschappen tot uitdrukking komen bij het identificeren van bedrijfsrisico's en organisatiebrede interne beheersingsmaatregelen. Nader onderzoek zal moeten uitwijzen in hoeverre de in dit artikel gerapporteerde uitkomsten algemene geldigheid hebben voor andere branchespecialismen.

Dit onderzoek kent - net als elk ander onderzoek een aantal onderzoekstechnische beperkingen. Deze beperkingen kunnen aanleiding zijn voor aanvullend toekomstig onderzoek. De kwaliteit van oordeelsvorming is in dit onderzoek gemeten door een nauwkeurigheidsvariabele die is afgeleid van de inschattingen van een expert panel. Andere empirische studies gebruiken het gevonden optimum van een van de onderzoeksdeelnemers soms als benchmark. In dit onderzoek was dat niet mogelijk angezien in de vraagstelling een maximum van te identificeren factoren besloten lag. In onze optiek is het aantal factoren dat een accountant identificeert geen goede voorspeller van de kwaliteit van die identificatie. Er kunnen immers ook niet-relevante factoren tussen zitten. Een beperking in dit onderzoek is dat de vraagstelling aan het expert panel inzake de identificatie van organisatiebrede interne beheersingsmaatregelen niet geheel aansloot op de vraagstelling aan de onderzoeksdeelnemers.
Een daaraan gerelateerde beperking is dat onderzoeksdeelnemers gevraagd werd de geïdentificeerde bedrijfsrisico's en organisatiebrede interne beheersingsmaatregelen in hun eigen woorden te beschrijven. Dit impliceert dat de gekozen bewoordingen dienden te worden gelabeld versus de door het expertpanel gekozen bewoordingen. Hoewel bepaalde procedures zijn uitgevoerd om de kwaliteit van dit labelingproces zo hoog mogelijk te doen zijn, is het toch een zekere beperking van de externe validiteit.

De onderzoeksresultaten suggereren dat een verdere toename van branchespecifieke ervaring vanaf een bepaald niveau van ervaring geassocieerd wordt met een daling in de performance. Hoe verhoudt dit onderzoeksresultaat (ex post) zich tot het gekozen construct waarbij de norm voor de performance bepaald wordt door expertaccountants met bijzonder veel branchespecifieke ervaring? Hierbij dient bedacht te worden dat de accountants die hebben deelgenomen aan het experiment in de accountantspraktijk werkzaam waren in de functie van (senior) manager, terwijl in het expertpanel alleen partners zitting hadden. Er ligt aan het construct daarom een expliciet gemaakte veronderstelling ten grondslag, namelijk dat partners - die bovendien aan zeer selecte criteria moesten voldoen - over andere vaardigheden en kennis beschikken dan managers. Partners hebben doorgaans ook een grotere cliëntenportefeuille dan managers waardoor het risico op blinde vlekken ook lager is. Het gekozen construct is daarom naar mijn mening daarom ook bruikbaar voor toekomstige onderzoeken, met als kanttekening dat de samenstelling van het expert panel dan kritisch dient te worden overwogen. Een tweede beperking is dat de focus van dit onderzoek heeft gelegen op de bouwbranche. Hierdoor is het niet goed mogelijk de resultaten te generaliseren naar andere (bijvoorbeeld meer gereguleerde) branches. Het is aan te bevelen om in toekomstig onderzoek een directe vergelijking tussen branches te maken. De studie van Solomon e.a. (1999) is in dat verband een goed voorbeeld.

\section{Gebruikte literatuur}

\footnotetext{
Abdolmohammadi, M.J., en A.M. Wright (1987), An examination of the effects of experience and task complexity on audit judgments, The Accounting Review, vol. 62, no. 1, pp. 1-13.

Bedard, J.C., en S.F. Biggs (1991a), The effect of domain-specific experience on evaluation of management representations in analytical procedures, Auditing: A Journal of Practice and Theory, vol.10, supplement, pp. 77-90.

Bedard, J.C., en S.F. Biggs (1991b), Pattern recognition, hypotheses generation, and auditor performance in an analytical task, The Accounting Review, vol. 68, no. 3, pp. 622-642.
} 
Bedard, J.C., en L.E. Graham (2002), The effects of decision aid orientation on risk factor identification and audit test planning, Auditing: A Journal of Practice \& Theory, vol. 21, no. 2, pp. 39-56.

Bell, T., F. Marrs, I. Solomon, en H. Thomas (1997), Auditing organizations through a strategic-systems lens, the KPMG Business Measurement Process, KPMG Peat Marwick LLP.

Bell, T.B., M.E. Peecher, en I. Solomon (2005), The 21st century public company audit, conceptual elements of KPMG's global audit methodology, KPMG International, 2005.

Bonner, S.E. (1990), Experience effects in auditing: the role of task-specific knowledge, The Accounting Review, vol. 65, no. 1, pp. 72-92.

Bonner, S.E., en B.L. Lewis (1990), Determinants of auditor expertise, Journal of Accounting Research, vol. 28, supplement, pp. 1-28.

Buuren, J. van (2006), Modernisering accountantscontrole lastig, De Accountant, jg. 112, no. 5 (januari), pp. 38-41.

Conlisk, J. (1996), Why bounded rationality?, Journal of Economic Literature, vol.34, no. 2, pp. 669-700.

Davis, J.S., I. Solomon (1989), Experience, expertise, and expert-performance research in public accounting, Journal of Accounting Literature, vol. 8, pp. 150-164.

Early, C.E. (2002), The differential use of information by experienced and novice auditors in the performance of ill-structured audit tasks, Contemporary Accounting Research, vol. 19, no. 4, pp. 595-614.

Hogan, C.E., en D.C. Jeter (1999), Industry specialization by auditors, Auditing: A Journal of Practice \& Theory, vol. 18, no. 1, pp. 165-194.

International Federation of Accountants (IFAC) (2003), International Standard on Auditing 315, Obtaining an understanding of the entity and its environment and assessing the risks of material misstatement.

Kloosterman, H. (2004), Wat is eigenlijk risicoanalyse in de accountantscontrole?, Maandblad voor Accountancyen Bedrijfseconomie, jg. 78, no. 12 (december), pp. 570-578.

Knechel, W.R. (2001), Auditing, assurance \& risk, (2nd edition), SouthWestern.

Knechel, W.R. (2007), The business risk audit: origins, obstacles and opportunities, Accounting, Organizations and Society, vol. 32, pp. 383408.

Koning, W.F. de (2002), Beoordeling van de interne controle in het kader van de accountantscontrole, Maandblad voor Accountancy en Bedrijfseconomie, jg. 76, no. 6 (juni), pp. 272-280.

Koninklijk NIVRA (2005), Risicoanalyse en interne controle, Richtlijn 400, Richtlijnen voor de Accountantscontrole.

Kotchetova, N.V. (2002), An analysis of client's strategy content and strategy process: impact on risk assessment and audit planning, Thesis Georgia State University, Robinson College of Business.

Lemon, W.M., K.W. Tatum, en W.S. Turley (2000), Developments in the audit methodologies of large accounting firms, Monograph.

Mollema, K. (2003), Auditrisico, meer dan ooit een issue! (1), Maandblad voor Accountancy en Bedrijfseconomie, jg. 77, no. 12 (december), pp. 551-556.

Nieuw Amerongen, C.M. van (2007), Auditor's performance in risk and control judgments, Academisch proefschrift, Vrije Universiteit Amsterdam. Zie: http://hdl.handle.net/1871/10691.

Nieuw Amerongen, C.M. van, (2007), Experience effects and the auditor's judgment performance in the identification of client's business risks and entity-level controls, Working paper, EAA Conference Lisbon.

Public Company Accounting Oversight Board (2006), An audit of internal control over financial reporting that is integrated with an audit of financial statements, PCAOB Release 2006-007. Zie: www.pcaob.org.

Porter, M.E. (1998), Competitive advantage: creating and sustaining superior performance, The Free Press.

Solomon, I., M.D. Shields, en O.R. Whittington (1999), What do industryspecialist auditors know?, Journal of Accounting Research, vol. 37, no. 1, pp. 191-208.

Taylor, M.H. (2000), The effects of industry-specialization on auditors' inherent risk assessments and confidence judgments, Contemporary Accounting Research, vol. 17, no. 4, pp. 693-712.

Trotman, K.T. (1998), Audit judgment research - Issues addressed, research methods and future directions, Accounting and Finance, vol. 38, no. 2, pp. 115-156.

Wright, W.F. (1988), Audit judgment consensus and experience, in: K.R. Ferris (ed.), Behavioral accounting research: a critical analysis, pp. 305-328.

Wright, S., en A.M. Wright (1997), The effect of industry experience on hypothesis generation and audit planning decisions, Behavioral Research in Accounting, vol. 9, pp. 273-294.

\section{Noten}

1 Auditing Standard No.5 (PCAOB, 2006) hanteert de term "companylevel controls". Dergelijke interne beheersingsmaatregelen kunnen in het kader van de geïntegreerde jaarrekeningcontrole onder andere betrekking hebben op de interne beheersingsomgeving, de door de cliënt opgestelde risicoanalyse, het proces van periodeafsluiting, monitoring van de organisatie, etc. 